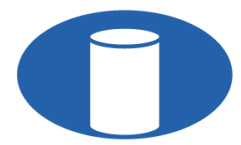

IBRACON Structures and Materials Journal

Revista IBRACON de Estruturas e Materiais

IBRACON

ISSN 1983-4195

ismj.org

ORIGINAL ARTICLE

\title{
Optimum design of a composite floor system considering environmental and economic impacts
}

\section{Otimização de sistema de piso misto de aço e concreto considerando o impacto ambiental e econômico}

\author{
Paulo Augusto T. Arpini ${ }^{\mathrm{a}}$ (D) \\ Mayane C. Loureiro ${ }^{\mathrm{a}}$ (D) \\ Breno D. Breda ${ }^{\mathrm{a}}$ (D) \\ Adenílcia F. Calenzani ${ }^{\mathrm{a}}$ (1) \\ Élcio C. Alves ${ }^{\mathrm{a}}$
}

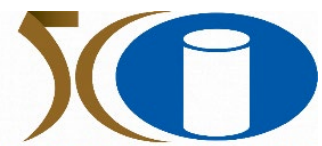

${ }^{a}$ Universidade Federal do Espírito Santo - UFES, Departamento de Engenharia Civil, Vitória, ES, Brasil

Received 15 April 2021

Accepted 16 September 2021

\begin{abstract}
The composite floor system, composed of steel deck and concrete slab, generates more efficient and economical structures. On the other hand, the design of this type of structure has a high complexity level due to the consideration of several variables. In this respect, the objective of this paper is to present the formulation of the optimization problem for a composite floor system (steel and concrete) considering such environmental as economic impacts. To formulate the optimization problem, the reduction of environmental impact was adopted as an objective function - assuming the $\mathrm{CO}_{2}$ emission and the finance cost as parameters. The restrictions were taken by the limiting states imposed in standard NBR 8800:2008. The computer program was developed via Matlab R2016a and the optimization process was carried out using the Genetic Algorithm toolbox existing in this platform. Two application examples of the formulation at hand are presented: the first from the literature and the second from an existing building - in both situations the influences of different concrete compressive characteristic strengths were analyzed. The results of the optimization problem show a reduction in geometry and, consequently, in its weight. The solution found by the program reduces by up to $17.70 \%$ of $\mathrm{CO}_{2}$ emissions and $17.47 \%$ of the finance cost. When was applying different concrete compressive strengths, the optimal solution for environmental impact did not get the lowest cost. In general, the steel deck formwork obtained the highest percentage of environmental impact, while the beams and girders, with the same shape configuration, had the highest finance cost. Therefore, it is shown that the optimal design solution to $\mathrm{CO}_{2}$ emissions is not always the better solution for the finance cost.
\end{abstract}

Keywords: steel-concrete composite floor system, cost and environmental impact, genetic algorithm.

Resumo: O sistema de piso misto, composto por steel deck e laje de concreto, gera estruturas mais eficientes e econômicas. Por outro lado, o dimensionamento deste tipo de estrutura apresenta um elevado nível de complexidade devido à consideração de várias variáveis. Nesse sentido, o objetivo deste trabalho é apresentar a formulação de um problema de otimização para um sistema de piso misto (aço e concreto) considerando os impactos ambientais e econômicos. Para formular o problema, a redução do impacto ambiental foi adotada como função objetivo - assumindo como parâmetros da otimização a emissão de $\mathrm{CO}_{2} \mathrm{e}$ o custo financeiro. As restrições foram atendidas pelos estados limitadores impostos na norma NBR 8800:2008. A rotina foi desenvolvida via Matlab R2016a e o processo de otimização foi realizado utilizando o Algoritmo Genético existente na plataforma. São apresentados dois exemplos de aplicação da formulação em questão: o primeiro da literatura e o segundo de um edifício existente - em ambas as situações foram analisadas as influências de diferentes resistências características à compressão do concreto. Os resultados do problema de otimização mostram uma redução na geometria e, consequentemente, no seu peso. A solução encontrada pelo programa reduz em até $17.70 \%$ as emissões de $\mathrm{CO}_{2}$ e até $17.47 \%$ o custo financeiro. Quando se aplicou diferentes

Corresponding author: Paulo Augusto T. Arpini. E-mail: paulo.a.arpini@edu.ufes.br

Financial support: None.

Conflict of interest: Nothing to declare.

Data Availability: The data that support the findings of this study are available from the corresponding author, PATA, upon reasonable request. 
resistências à compressão do concreto, a solução ótima de impacto ambiental não obteve o menor custo. Em geral, a fôrma de steel deck obteve o maior percentual de impacto ambiental, enquanto as vigas secundárias e principais, com a mesma configuração de forma, tiveram o maior custo financeiro. Portanto, mostra-se que a solução de projeto ideal para as emissões de $\mathrm{CO}_{2}$ nem sempre é a melhor solução para o custo financeiro.

Palavras-chave: sistema de piso misto de aço-concreto, custo e impacto ambiental, algoritmo genético.

How to cite: P. A. T. Arpini, M. C. Loureiro, B. D. Breda, A. F. Calenzani, and E. C. Alves, "Optimum design of a composite floor system considering environmental and economic impacts", Rev. IBRACON Estrut. Mater., vol. 15, no. 3, e15302, 2022, https://doi.org/10.1590/S198341952022000300002

\section{INTRODUCTION}

During the conception of a structural system, several different variables must be considered (dimension of structural elements, materials, cost, constructive process, among others), to define the most adequate design solution from technical, cost, and environmental perspectives. The latter is of great importance for the current worldwide scenario, and it is considered a strategic advantage, paramount for the sustainable development of civil construction.

On the quest for perfecting engineering processes, design optimization is a tool capable of offering good results for the solution of problems concerning the analysis and design of structures. As such, metaheuristic methods are studied, inspired in nature and its biological processes.

Optimization problems in civil construction usually involve finding the most financially viable solution. Recently, Öztürk et al. [1] used the TLBO and Jaya algorithms, while Kalemci et al. [2] used the Gray Wolf Optimization algorithm (GWO) to optimize the ideal design of a reinforced concrete retaining wall, to minimize the cost and weight of the structure, respectively.

Genetic Algorithms (GA) were proposed by John Holland in the 1960s. Those are models inspired by the principles of natural selection proposed by Charles Darwin. Considered one of the most consolidated metaheuristic methods, the application of GA's is observed in numerous areas, since this method presents high efficiency for finding globally optimized solutions [3].

Examples of GA applied to structural engineering include the optimization of reinforced concrete beams [4], [5], steel-concrete composite girders [6], spatial steel frames [7], railway viaducts [8] and bridges [9], [10].

It is worth noting that the optimized solution is not always the best alternative when problem variables are subjected to a specific type of constraint. Kripakaran et al. [11] developed a decision-making support system based on GA for the structural optimization of rigid steel frames and used the Modelling to Generate Alternatives (MGA) technique to determine structural solutions as close as possible to the optimized alternative. The ideal solution was chosen from a set of options that presented the best results.

From financial and environmental standpoints, the use of steel-concrete composite structures gained notoriety in civil construction for presenting performance improvements because of combining the use of both materials.

The presence of different materials increases the number of variables involved in the design of composite structures, making a more complex calculations and time-consuming if the conventionally used trial and error approach is adopted [12]. However, manufacturers usually provide design tables for specific structural elements such as steel decks, which are ideal tools for implementing optimization techniques featuring discrete variables.

Numerous studies using different methods for the design optimization of steel-concrete composite structures are observed in scientific literature, such as Žula et al. [13], Matos et al. [14], Dede [15] and Shariati et al. [16], Kaveh and Abadi [17].

Kravanja et al. [18] presented the optimal designs of different steel-concrete composite floor systems connected to a welded "I" section. The study was conducted by implementing structural optimization via nonlinear programming.

Pedro et al. [19] studied the optimization of "I" section steel-concrete composite bridges in two steps. On the first, a model commonly adopted by bridge engineers was implemented, followed by a finite element analysis on the second to improve the optimization

Silva and Rodrigues [20] implemented the iterative method of linear sequential programming associated with the Simplex method for the design of steel-concrete composite girders, with the objective of reducing the cost of materials.

Silva et al. [21] used the sequential linear programming algorithm to optimize mixed steel and concrete beams with partial interaction. The method proved to be efficient in the optimization of the composite beams when considering different design variables.

Gervásio [22] classifies steel as an environmentally friendly material due to its recycling potential. However, the author stresses that $1 \mathrm{~kg}$ of steel produced in a blast furnace generates $2494 \mathrm{~g}$ of $\mathrm{CO}_{2}$, while the same weight of steel produced with an electric arc furnace generates $462 \mathrm{~g}$ of $\mathrm{CO}_{2}$. 
Paya-Zaforteza et al. [23] study the optimization of the cost and $\mathrm{CO}_{2}$ emissions of 6 reinforced concrete plane frames via Simulated Annealing algorithm. Results indicated that the most environmentally friendly solution is only $2.77 \%$ more expensive than the cheapest solution, while the latter presented an increase of $3.80 \%$ in $\mathrm{CO}_{2}$ emissions.

Tormen et al. [6] and Santoro and Kripka [12] presented studies on composite girders and, in addition to assessing the cost optimization of these elements, the authors state that the environmental impacts of using this type of girder are directly related to the degree of mechanical interaction between girders and slabs.

Despite the large number of studies on the optimization of steel-concrete composite structures available in scientific literature, research presenting both cost and environmental optimizations of systems featuring composite girders and slabs simultaneously are not observed. It is worth noting that, according to the International Energy Agency [24], civil construction accounted for $39 \%$ of total carbon dioxide $\left(\mathrm{CO}_{2}\right)$ emissions in 2018 .

This paper presents the formulation for optimizing floor systems featuring steel-concrete composite girders and slabs, with the objective of determining the structure with the lowest financial and environmental costs. The problem was solved using Genetic Algorithms implemented with the toolbox provided by the software MATLAB [25], considering structural safety criteria prescribed in ABNT NBR 8800:2008 [26]. The formulation proposed here was validated with the example presented by Fakury et al. [27] and a composite floor system of an existing structure designed by conventional methods is analyzed.

\section{THE PROBLEM FORMULATION}

This section presents the proposed formulation for minimizing $\mathrm{CO}_{2}$ emissions and other environmental costs of manufacturing the composite floor system shown in Figure 1, according to safety requirements for the structural materials used. The floor system is comprised of a composite slab supported by beams, a girder that supports the secondary beams parallel to the primary beams. The composite slab is molded on a trapezoidal steel deck and primary beam, girder and beams feature solid "I" sections. The shear connections are performed via stud bolts and for the structural model, the linear elastic behavior was considered.
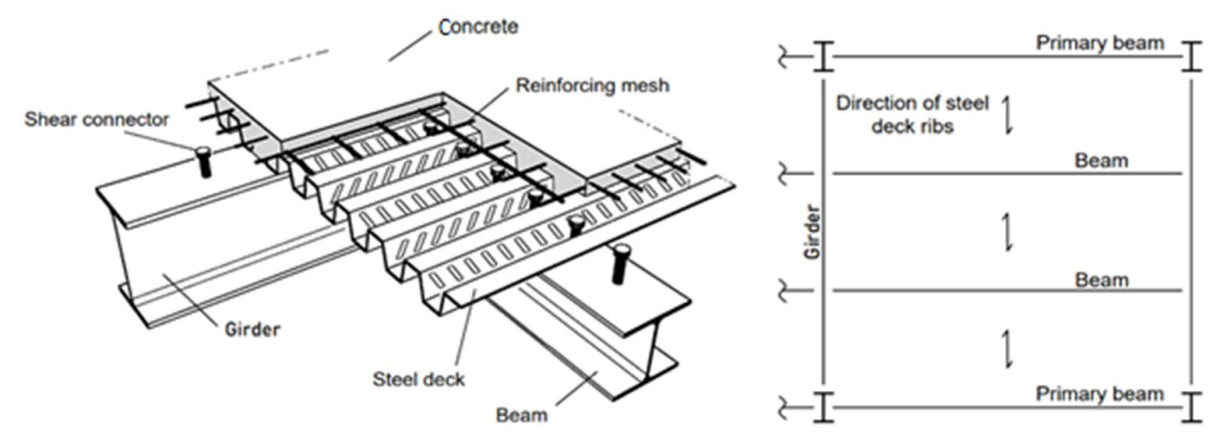

Figure 1. Composite floor with steel profiled sheeting (Adapted from Crisinel and Marimon 2004)

The design of the composite structural elements followed the standardized procedures provided by ABNT NBR 8800:2008 [26], based on limit-state design. It's Annex O of the standard prescribes the guidelines for the design of steel-concrete composite beams, while the design procedure for steel-concrete composite slabs is shown in Annex Q. Breda et al. [28] presented a formulation for the optimization problem analyzed here. However, the analysis performed by the authors was limited to cost optimization of the slabs and primary beams.

\subsection{Choice variables}

The decisions variables are the individuals that change during the optimization process. In the computer program, they are inserted using a $1 \times 7$ vector, whose data are:

$x_{1}$ : Profile determination of the Gerdau [29] catalog from where the dimensions for the parallel, secondary, and main beams are obtained. The range ranges from 1 to 88 for laminated profile and 1 to 174 for welded profiles of the VS series; $x_{2}$ : The degree of beam-slab interaction of the secondary and main beam with values from $\alpha_{\min }$ to 1 ; 
$x_{3}$ : The total height of the slab and the thickness of the formwork according to the Metform [30] catalog.

$x_{4}$ : The maximum span of the slab according to the Metform [30] catalog.

$x_{5}$ : The type of formwork according to the Metform [30] catalog. The value of 1 was assigned to MF-50 and 2 to MF-75.

The values for the thickness of the steel deck are defined in accordance with the table provided by the company Metform. That are three thicknesses for the steel sheet $(0.8,0.95$ and $1.25 \mathrm{~mm})$ and eight total heights for each type of geometry: for MF50, the height varies from $100 \mathrm{~mm}$ to $170 \mathrm{~mm}$ and for MF-75 from $130 \mathrm{~mm}$ to $200 \mathrm{~mm}$. Thus, choosing one of the three steel deck thicknesses and one the eight available total heights result in twenty-four combinations.

The steel profiles are limited to the values given in table from Gerdau [29], the smallest profile is the W $150 \times 13$ and the largest, $\mathrm{W} 610 \times 217$. The steel wire mesh is defined according to stipulations from the steel deck manufacturer, and the diameter. The wires varying from Q-75 $(\varnothing 3.8 \times ø 3.8-150 \times 150)$ to Q-138 $(\varnothing 4.2 \times ø 4.2-100 \times 100)$. Transverse reinforcements were designed with $8 \mathrm{~mm}$ reinforcement bars and welded wire mesh Q-75 $(\varnothing 3.8 \times ø 3.8-150 \times 150)$ to ensure that the minimum steel area is provided when necessary.

Figure 2 shows the cross section of the system indicating the dimensions of the profile and slab geometry that are obtained through the Gerdau [29] and Metform [30] catalog, respectively. $h$ corresponds to the height of the web, $b_{f}$ the width of the flanges, $t_{w}$ the thickness of the web, $t_{f}$ the thickness of the flanges, $t_{c}$ the height of the concrete slab, $b$ the effective width of the concrete slab and $\mathrm{h}_{\mathrm{f}}$ the height of the ribs of the shaped slab steel incorporated.

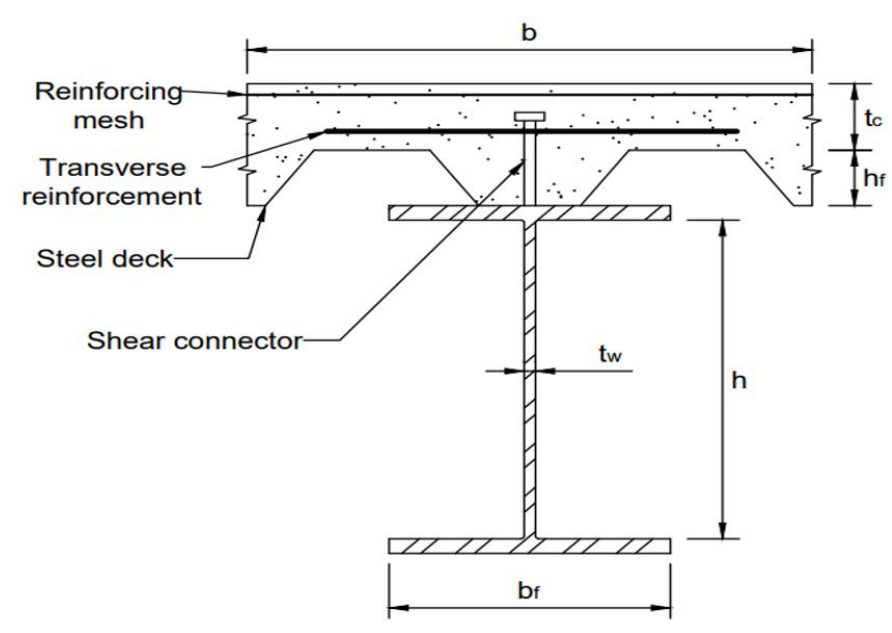

Figure 2. Cross-section of the composite girder and composite slab.

\subsection{Objective function}

The objective function for optimizing environmental impact, given in $\mathrm{kg}$ of $\mathrm{CO}_{2}$ emission, is presented in Equation 1.

Minimize $\mathrm{CO}_{2}=\mathrm{CO}_{2(\text { beam })}+\mathrm{CO}_{2(\text { formwork })}+\mathrm{CO}_{2(\text { concrete })}+\mathrm{CO}_{2(\text { mesh })}$

where $\mathrm{CO}_{2 \text { (beam) }}$ corresponds to the $\mathrm{CO}_{2}$ emissions of the steel profile, transverse reinforcement and shear connector of the primary beam and beams given by the sum of Equation 2 and 3 .

$$
C O_{2(\text { beam }) V S P}=\left(2+n_{\text {beam }}\right) \cdot\left[\left(\rho_{\text {steel }} \cdot A_{a} \cdot L \cdot E_{\text {steel }}\right)+\left(n \cdot \rho_{\text {steel }} \cdot V_{c} \cdot E_{\text {steel }}\right)+\left(A_{S} \cdot l_{b} \cdot \rho_{\text {steel }} \cdot E_{\text {steel }}\right)\right]
$$

with the first term of the equation corresponding to the sum of beams, represented by $n_{\text {beams }}$, and two parallel primary beams, while $\rho_{\text {steel }}$ is the specific mass of the steel from the profile in $\mathrm{kg} / \mathrm{m}^{3}, A_{a}$ is the cross-sectional area of profiled steel $\left(\mathrm{m}^{2}\right), \mathrm{L}$ is the length of the beam $(\mathrm{m}), E_{\text {steel }}$ is the $\mathrm{CO}_{2}$ emission of steel $\left(\mathrm{kgCO}_{2} / \mathrm{kg}\right), \mathrm{n}$ is the number of stud bolt 
connectors, $V_{c}$ is the volume of the stud bolt connector $\left(\mathrm{m}^{3}\right), A_{s}$ is the area of transverse reinforcement $\left(\mathrm{m}^{2}\right)$ and $l_{b}$ is the anchorage length of the transverse reinforcement (m).

$$
C O_{2(\text { beam }) V P}=\left(V_{\text {steel }} \cdot E_{\text {steel }} \cdot \rho_{\text {steel }}\right)+\left(n_{p} \cdot V_{c} \cdot \rho_{\text {steel }} \cdot E_{\text {steel }}\right)+\left(A_{s p} \cdot l_{b p} \cdot \rho_{\text {steel }} \cdot E_{\text {steel }}\right)
$$

where $V_{\text {steel }}$ is the volume of the girder, perpendicular to the beams $\left(\mathrm{m}^{3}\right), n_{p}$ is the number of stud bolt connectors on the girder, $A_{s p}$ is the area of transverse reinforcement of the girder $\left(\mathrm{m}^{2}\right)$ and $l_{b p}$ the anchorage length of the transverse reinforcement on the girder $(\mathrm{m})$.

$\mathrm{CO}_{2 \text { concrete, }}$ is the $\mathrm{CO}_{2}$ emission of concrete determined with Equation 4.

$$
\mathrm{CO}_{2(\text { concrete })}=E_{\text {conc }} \cdot A_{\text {slab }} \cdot v_{\text {conc }}
$$

where $E_{\text {conc }}$, is the $\mathrm{CO}_{2}$ emission of concrete $\left(\mathrm{kgCO}_{2} / \mathrm{m}^{3}\right), A_{\text {slab }}$ is the rectangular area of the slab covered by the steel deck $\left(\mathrm{m}^{2}\right)$ and $v_{\text {conc }}$ is usage of concrete $\left(\mathrm{m}^{3} / \mathrm{m}^{2}\right)$.

$\mathrm{CO}_{2 \text { (formwork) }}$ is the emission of the steel deck determined by Equation 5 .

$$
C O_{2(\text { formwork })}=A_{\text {slab }} \cdot p_{\text {formwork }} \cdot E_{\text {sd }}
$$

where $p_{\text {formwork }}$ is the weight of the steel deck $\left(\mathrm{kg} / \mathrm{m}^{2}\right)$ and $E_{s d}$ the $\mathrm{CO}_{2}$ emission of the steel deck $\left(\mathrm{kgCO}_{2} / \mathrm{kg}\right)$.

$\mathrm{CO}_{2 \text { (mesh) }}$ represents the emission of the reinforcing mesh given by Equation 6 .

$$
\mathrm{CO}_{2(\mathrm{mesh})}=A_{\text {slab }} \cdot p_{\text {mesh }} \cdot E_{\text {mesh }}
$$

where $\mathrm{p}_{\text {mesh }}$ is the weight of the mesh $\left(\mathrm{kg} / \mathrm{m}^{2}\right)$ and $\mathrm{E}_{\text {tela }}$ is the corresponding $\mathrm{CO}_{2}$ emission $(\mathrm{kgCO} / \mathrm{kg})$.

\subsection{Constraints}

The constraint functions are based on ABNT NBR 8800:2008 [26] Annex O design recommendations, given by Equation 7:

$$
C=\left\{\begin{array}{c}
\frac{h_{w} / t_{w}}{5.7 \sqrt{E / f_{y k}}}-1 \leq 0 \\
\frac{\alpha_{\min }}{\alpha}-1 \leq 0 \\
\frac{M_{s d}}{M_{r d}}-1 \leq 0 \\
\frac{V_{s d}}{V_{r d}}-1 \leq 0 \\
\frac{q_{s d}}{q_{r d}}-1 \leq 0 \\
\frac{\left(M_{G a, S k} / W_{a, i}\right)+\left(M_{L, S k} / W_{e f, i}\right)}{f_{y k}}-1 \leq 0 \\
\frac{\delta_{t}}{\delta_{a d m}}-1 \leq 0 \\
\frac{H_{v, S d}}{H_{v, R d}}-1 \leq 0
\end{array}\right.
$$


where $h_{w}$ is the height of the profile web (m), $t_{w}$ is the web thickness $(\mathrm{m}), \mathrm{E}$ is the modulus of elasticity of steel $\left(\mathrm{kN} / \mathrm{m}^{2}\right), f_{y k}$ the characteristic yield strength of steel of the profiles $\left(\mathrm{kN} / \mathrm{m}^{2}\right), \alpha_{\min }$ minimum allowable interaction between beam and slab according to ABNT NBR 8800:2008 [26], $\alpha$ the degree of interaction between beam and slab, $M_{s d}$ the design bending moment acting on the beam $(\mathrm{kN} \cdot \mathrm{m}), M_{r d}$ the design resistance to bending moment $(\mathrm{kN} \cdot \mathrm{m}), V_{s d}$ is the design shear force acting on the structure $(\mathrm{kN}), V_{r d}$ the design resistance of shear force $(\mathrm{kN}), q_{s d}$ the uniformly distributed live load on the slab $\left(\mathrm{kN} / \mathrm{cm}^{2}\right), q_{r d}$ is the live-load capacity of the slab $\left(\mathrm{kN} / \mathrm{m}^{2}\right)$, obtained from design tables provided by Metform [30], $M_{G a, S k}$ and $M_{L, S k}$ are the design bending moments on the structure before and after concrete curing, respectively $(\mathrm{kN} \cdot \mathrm{m}), W_{\text {effi }}$ is the inferior elastic section modulus of the transformed section $\left(\mathrm{m}^{3}\right), W_{a, i}$ is the inferior elastic section modulus of the steel profile $\left(\mathrm{m}^{3}\right), \delta_{t}$ is the total deflection $(\mathrm{mm})$ and $\delta_{a d m}$ is the maximum allowable deflection $(\mathrm{mm}), H_{v, S d}$ is the design shear force acting on the slab $(\mathrm{kN} / \mathrm{m}), H_{v, R d}$ is the corresponding design resistance to shear force $(\mathrm{kN} / \mathrm{m})$.

\section{RESULTS AND DISCUSSIONS}

Two numerical examples are presented to verify the efficiency of the formulation proposed in this paper, one of which extracted from Fakury et al. [27] and the other corresponds to an existing structure featuring composite floor systems. The material properties common to both examples are Modulus of elasticity of steel $(E): 200 \mathrm{GPa}$; Tensile strength of steel of the beams $\left(f_{y k}\right): 345 \mathrm{MPa}$; Diameter of shear connectors $\left(d_{c s}\right): 1.9 \mathrm{~cm}$; Tensile strength of steel of the shear connectors $\left(f_{u c s}\right): 415 \mathrm{MPa}$; Coefficient for consideration of connector grouping $\left(R_{g}\right)$ : 1 ; Coefficient for considering the position of connectors $\left(R_{p}\right)$ : 0.6. It is worth mentioning that, for simplicity, $R_{p}$ was considered in the most unfavorable situation, that is, connectors welded on a mixed slab with ribs perpendicular to the steel profile and the distance from the half height of the web of the form rib to the face of the connector shaft less than $50 \mathrm{~mm}$. The parameter chosen to measure the environmental impact was the $\mathrm{CO}_{2}$ emission resulting from construction processes, considering the total carbon footprint generated from raw material extraction to the final product. Table 1 presents the reference values of $\mathrm{CO}_{2}$ emissions used in this study.

Table 1. $\mathrm{CO}_{2}$ emission of materials

\begin{tabular}{|c|c|c|c|c|c|c|c|}
\hline \multirow[t]{2}{*}{ Material } & \multirow[t]{2}{*}{ Unit } & $\begin{array}{c}\mathrm{CO}_{2} \\
\text { emissions }\end{array}$ & \multirow[t]{2}{*}{ Reference } & \multirow[t]{2}{*}{ Material } & \multirow[t]{2}{*}{ Unit } & $\begin{array}{c}\mathrm{CO}_{2} \\
\text { emissions }\end{array}$ & \multirow[t]{2}{*}{ Reference } \\
\hline & & $\left(\mathrm{kgCO}_{2}\right)$ & & & & $\left(\mathrm{kgCO}_{2}\right)$ & \\
\hline Concrete $20 \mathrm{MPa}$ & $\mathrm{m}^{3}$ & 130.68 & \multirow{7}{*}{$\begin{array}{l}\text { Santoro and Kripka } \\
{[12]}\end{array}$} & Steel deck & $\mathrm{kg}$ & 26.38 & \multirow{7}{*}{$\begin{array}{c}\text { Worldsteel } \\
\text { Association } \\
\text { [31] }\end{array}$} \\
\hline Concrete $25 \mathrm{MPa}$ & $\mathrm{m}^{3}$ & 139.88 & & Steel profile & \multirow[b]{2}{*}{$\mathrm{kg}$} & \multirow[b]{2}{*}{11.16} & \\
\hline Concrete $30 \mathrm{MPa}$ & $\mathrm{m}^{3}$ & 148.28 & & $\begin{array}{l}\text { Studbolt shear } \\
\text { connector }\end{array}$ & & & \\
\hline Concrete $35 \mathrm{MPa}$ & $\mathrm{m}^{3}$ & 162.36 & & $\begin{array}{l}\text { Reinforcing steel } \\
\text { mesh }\end{array}$ & \multirow{2}{*}{$\mathrm{kg}$} & \multirow{2}{*}{19.24} & \\
\hline Concrete $40 \mathrm{MPa}$ & $\mathrm{m}^{3}$ & 172.77 & & $\begin{array}{l}\text { Steel CA50, } 8 ~ \\
\text { mm, } \\
\text { reinforcement bar }\end{array}$ & & & \\
\hline Concrete $45 \mathrm{MPa}$ & $\mathrm{m}^{3}$ & 185.32 & & & & & \\
\hline Concrete $50 \mathrm{MPa}$ & $\mathrm{m}^{3}$ & 216.40 & & & & & \\
\hline
\end{tabular}

The cost of the materials was obtained by consulting manufacturers or from other scientific studies, indicated in Table 2. The prices of concrete, steel profiles and reinforcing steel mesh were reproduced from SINAPI [32]. The cost of stud bolt connectors was obtained from Cordeiro [33] and the cost of the steel decks was provided by the MS Estruturas Metálicas (2020) company. 
Table 2. Cost of materials

\begin{tabular}{|c|c|c|c|c|c|c|c|}
\hline Material & Unit & $\frac{\text { Cost }}{(\mathbf{R} \$)}$ & Reference & Material & Unit & $\frac{\text { Cost }}{(\mathbf{R} \$)}$ & Reference \\
\hline Concrete $20 \mathrm{MPa}$ & $\mathrm{m}^{3}$ & 295.00 & \multirow{9}{*}{ SINAPI [32] } & $\begin{array}{l}\text { Steel CA-50, } \varnothing 8 \mathrm{~mm} \text {, } \\
\text { reinforcement bar }\end{array}$ & $\mathrm{kg}$ & 5.34 & SINAPI [32] \\
\hline Concrete $25 \mathrm{MPa}$ & $\mathrm{m}^{3}$ & 307.42 & & $\begin{array}{c}\text { Stud bolt shear } \\
\text { connector }\end{array}$ & un & 11.40 & Cordeiro [33] \\
\hline Concrete $30 \mathrm{MPa}$ & $\mathrm{m}^{3}$ & 317.11 & & $\begin{array}{l}\text { Steel deck MF-50, } \\
\text { thickness } 0.80 \mathrm{~mm}\end{array}$ & $\mathrm{~m}^{2}$ & 72.36 & \multirow{7}{*}{$\begin{array}{l}\text { MS Estruturas } \\
\text { Metálicas [34] }\end{array}$} \\
\hline Concrete $35 \mathrm{MPa}$ & $\mathrm{m}^{3}$ & 329.15 & & $\begin{array}{l}\text { Steel deck MF-50, } \\
\text { thickness } 0.95 \mathrm{~mm}\end{array}$ & $\mathrm{~m}^{2}$ & 80.96 & \\
\hline Concrete $40 \mathrm{MPa}$ & $\mathrm{m}^{3}$ & 341.57 & & $\begin{array}{l}\text { Steel deck MF-50, } \\
\text { thickness } 1.25 \mathrm{~mm}\end{array}$ & $\mathrm{~m}^{2}$ & 104.54 & \\
\hline Concrete $45 \mathrm{MPa}$ & $\mathrm{m}^{3}$ & 384.01 & & $\begin{array}{l}\text { Steel deck MF- } 75 \text {, } \\
\text { thickness } 0.80 \mathrm{~mm}\end{array}$ & $\mathrm{~m}^{2}$ & 83.29 & \\
\hline Concrete $50 \mathrm{MPa}$ & $\mathrm{m}^{3}$ & 455.43 & & $\begin{array}{l}\text { Steel deck MF-75, } \\
\text { thickness } 0.95 \mathrm{~mm}\end{array}$ & $\mathrm{~m}^{2}$ & 93.18 & \\
\hline Steel profile & $\mathrm{kg}$ & 9.47 & & $\begin{array}{l}\text { Steel deck MF-75, } \\
\text { thickness } 1.25 \mathrm{~mm}\end{array}$ & $\mathrm{~m}^{2}$ & 120.31 & \\
\hline $\begin{array}{l}\text { Reinforcing steel } \\
\text { mesh }\end{array}$ & $\mathrm{kg}$ & 7.96 & & & & & \\
\hline
\end{tabular}

\subsection{Example 1 - Fakury, Silva and Caldas}

The example from Fakury et al. [27] presents a floor system from a commercial building located in a moderate environmental aggressiveness zone. The system features a composite slab with steel deck MF-75 of $0.95 \mathrm{~mm}$ thickness, $15.0 \mathrm{~cm}$ of height, reinforcing mesh Q-75 $(\varnothing 3.8 \times \varnothing 3.8-150 \times 150)$ and concrete with a compressive strength of $25 \mathrm{MPa}$, manufactured using gneiss as aggregate. The beams V1 are simply supported and comprised of the laminated profile W $310 \times 28,3$, while the girder V3 features the monosymmetric welded profile VSM $450 \times 59$, with the narrowest flange in contact with the slab. The geometries of the floor and reference cross-section are given in Figure 3 and load factors for dead and live loads, considered here before and after concrete curing, are given in Table 3.
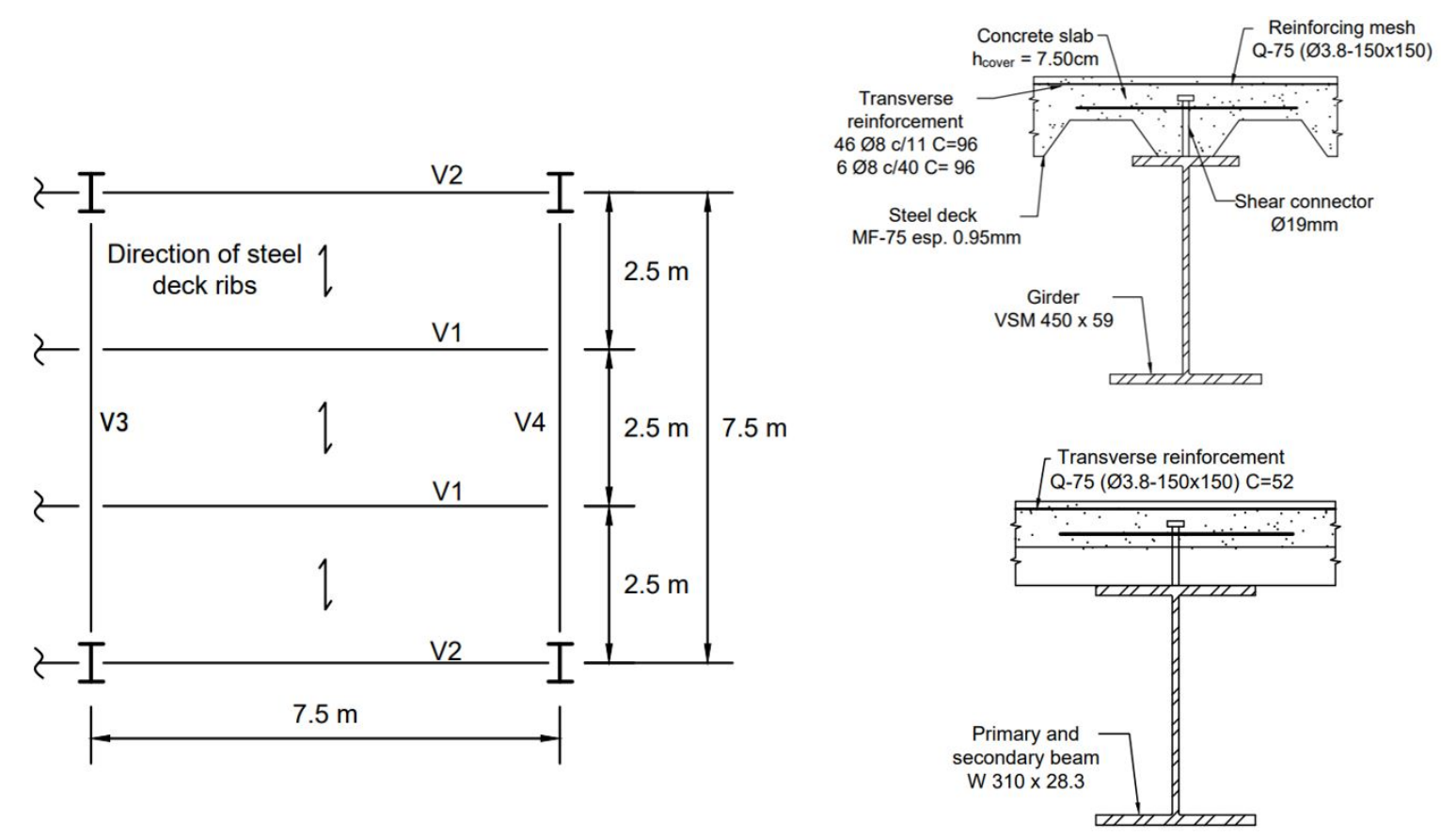

Figure 3. Geometry of the floor system from example 1 
Table 3. Loads before concrete curing

\begin{tabular}{|c|c|c|c|c|}
\hline & Load type & Load & $\begin{array}{c}\text { Characteristic value } \\
{\left[\mathrm{kN} / \mathrm{m}^{2}\right]}\end{array}$ & Load factor \\
\hline \multirow{2}{*}{$\begin{array}{l}\text { Before concrete } \\
\text { curing }\end{array}$} & Dead & Weight of the steel structure & 0.25 & 1.15 \\
\hline & Live & Construction live load & 1.00 & 1.30 \\
\hline \multirow{3}{*}{ After concrete curing } & \multirow{2}{*}{ Dead } & Weight of the steel structure & 0.25 & 1.25 \\
\hline & & Weight of the flooring & 1.35 & 1.50 \\
\hline & Live & Serviceability live load & 5.00 & 1.50 \\
\hline
\end{tabular}

Table 4 presents the results obtained by Fakury et al. [27] and results from the proposed formulation. The geometry and cross-section of the optimum solution indicated by the program are shown in Figure 4.
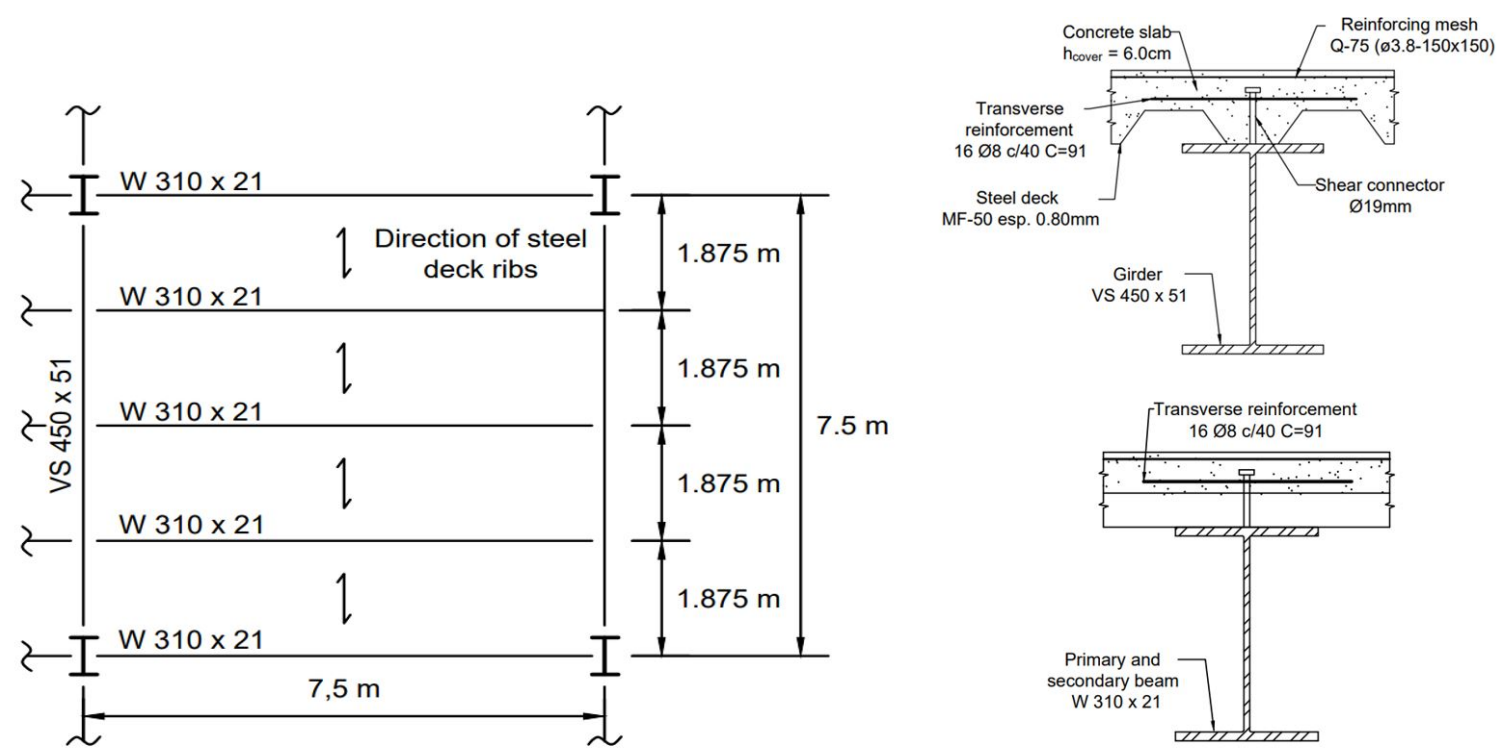

Figure 4. Optimal geometry of the floor system for example 1

Table 4. Results for example 1

\begin{tabular}{|c|c|c|c|}
\hline Information & Unit & Fakury et al. [27] & Optimized solution \\
\hline Number of beams & un & 2 & 3 \\
\hline Steel deck type & -- & MF-75 & MF-50 \\
\hline Steel deck thickness & $\mathrm{mm}$ & 0.95 & 0.80 \\
\hline Maximum span & $\mathrm{m}$ & 2.50 & 2.20 \\
\hline Total height of the slab & $\mathrm{cm}$ & 15.00 & 11.00 \\
\hline Thickness of the concrete layer & $\mathrm{cm}$ & 7.50 & 6.00 \\
\hline Reinforcing steel mesh & -- & Q-75 (ø3.8-150× 150) & Q-75 $(\varnothing 3.8-150 \times 150)$ \\
\hline Profile of the beam V1 & -- & W $310 \times 28.3$ & $\mathrm{~W} 310 \times 21$ \\
\hline Degree of composite interaction V1 & -- & 0.47 & 0.54 \\
\hline Total number of connectors V1 & un & 32 & 48 \\
\hline Transverse reinforcementV1 & & Q-75 $(\varnothing 3.8150 \times 150) \mathrm{C}=52$ & $16 ø 8 \mathrm{c} / 40 \mathrm{C}=91$ \\
\hline Profile of the primary beam V2 & -- & W $310 \times 28.3^{*}$ & W $310 \times 21$ \\
\hline Degree of composite interaction V2 & un & $0.47^{*}$ & 0.51 \\
\hline Total number of connectors V2 & -- & $32 *$ & 32 \\
\hline Transverse reinforcementV2 & & Q-75 (ø3.8-150×150) $\mathrm{C}=52^{*}$ & $16 ø 8 \mathrm{c} / 40 \mathrm{C}=91$ \\
\hline Profile of the girder V3 & -- & VSM $450 \times 59$ & VS $450 \times 51$ \\
\hline Degree of composite interaction V3 & -- & 0.65 & 0.71 \\
\hline Total number of connectors V3 & un & 32 & 28 \\
\hline Transverse reinforcement V3 & -- & $\begin{array}{c}46 ø 8 \mathrm{c} / 11 \mathrm{C}=96 \\
6 ø 8 \mathrm{c} / 40 \mathrm{C}=96\end{array}$ & $16 ø 8 \mathrm{c} / 40 \mathrm{C}=91$ \\
\hline
\end{tabular}

*Adopted Information 
Results from Table 4 shows that, despite the optimized solution indicating a larger number of shear connectors and beams, the profile section selected for said beams presents a lower linear weight in comparison with the reference example, while maintaining the same height.

The slab selected for the optimized solution presents a smaller height, with reductions of height for the steel deck and the concrete layer. Since the composite beam V2 are primary and internal, the optimization procedure selected the same profile used for the beams.

Table 5 shows a comparison between $\mathrm{CO}_{2}$ emission and cost obtained from the optimization program and from Fakury et al. [27].

Table 5. $\mathrm{CO}_{2}$ emission and cost for example 1

\begin{tabular}{|c|c|c|c|c|}
\hline \multirow[b]{2}{*}{ Information } & \multicolumn{2}{|c|}{ Fakury et al. [27] } & \multicolumn{2}{|c|}{ Optimization program } \\
\hline & $\begin{array}{c}\text { Environmental impact } \\
\left(\mathrm{kgCO}_{2}\right)\end{array}$ & Cost (R\$) & $\begin{array}{c}\text { Environmental impact } \\
\left(\mathrm{kgCO}_{2}\right)\end{array}$ & Cost (R\$) \\
\hline Beams V1 & 481.77 & 4434.9 & 517.52 & 4960.56 \\
\hline Primary beam V2 & 481.77 & 4434.9 & 345.016 & 3307.04 \\
\hline Girder V3 & 494.71 & 4535.2 & 436.07 & 3951.78 \\
\hline Transverse reinforcement & 35.7 & 123.7 & 31.52 & 102.36 \\
\hline Steel deck & 1661.9 & 5241.38 & 1390.39 & 4685.06 \\
\hline Concrete & 885.18 & 1945.39 & 806.5 & 1772.47 \\
\hline Reinforcing steel mesh & 130.95 & 541.78 & 130.95 & 541.78 \\
\hline TOTAL & 4171.98 & 21257.25 & 3657.966 & 19321.05 \\
\hline
\end{tabular}

As shown in Table 5, the environmental impact resulting from $\mathrm{CO}_{2}$ emission, indicates reductions in this parameter for the steel deck $(16.34 \%)$, concrete $(8.89 \%)$, Transverse reinforcement $(11.71 \%)$, girder V3 $(11.85 \%)$ and primary beam V2 (28.39\%). These results may be explained by reductions of the linear weight of the girders, number of connectors, along with steel deck and concrete layer thicknesses, which tends to reduce material consumption and consequently the rate of de $\mathrm{CO}_{2}$ emission. Since the reinforcing steel mesh used was the same for both approaches, no changes are observed for this material.

Furthermore, Table 5 also shows considerable reduction of cost when the optimized solution is implemented. The percentual reductions of cost were primary beam V2 (25.43\%) and girder V3 (12.86\%), transverse reinforcement $(17.25 \%)$, steel deck $(10.61 \%)$ and concrete $(8.89 \%)$. In a general perspective, the environmental optimization program presents a reduction in cost of $10.51 \%$.

A comparison between both responses reveals that, although the optimized alternative features a greater number of beams, the results correspond to a reduction of $12.32 \%$ and $9.11 \%$ of total cost and $\mathrm{CO}_{2}$ emission, respectively. Table 6 shows the compressive strength influences of concrete on the environmental impact of the optimized results.

Table 6. Results from example 1 for different values of $f_{c k}$

\begin{tabular}{|c|c|c|c|c|c|c|c|c|}
\hline Information & Unit & $20 \mathrm{MPa}$ & $25 \mathrm{MPa}$ & $30 \mathrm{MPa}$ & 35 MPa & $40 \mathrm{MPa}$ & $45 \mathrm{MPa}$ & 50 MPa \\
\hline Number of V1* & un & 3 & 3 & 3 & 3 & 3 & 3 & 3 \\
\hline Steel deck type & -- & MF-50 & MF-75 & MF-75 & MF-75 & MF-50 & MF-50 & MF-75 \\
\hline Steel deck thickness & $\mathrm{mm}$ & 0.80 & 0.80 & 0.80 & 0.80 & 0.80 & 0.80 & 0.80 \\
\hline Total height of the slab & $\mathrm{cm}$ & 11.00 & 14.00 & 14.00 & 14.00 & 11.00 & 11.00 & 14.00 \\
\hline Thickness of the concrete layer & $\mathrm{cm}$ & 6.00 & 6.50 & 6.50 & 6.50 & 6.00 & 6.00 & 6.50 \\
\hline Reinforcing steel Mesh & -- & $\begin{array}{c}\text { Q-75 (ø3.8- } \\
150 \times 150)\end{array}$ & $\begin{array}{c}\text { Q-75 (ø3.8- } \\
150 \times 150)\end{array}$ & $\begin{array}{c}\text { Q-75 (ø3.8- } \\
150 \times 150)\end{array}$ & $\begin{array}{c}\text { Q-75 (ø3.8- } \\
150 \times 150)\end{array}$ & $\begin{array}{c}\text { Q-75 (ø3.8- } \\
150 \times 150)\end{array}$ & $\begin{array}{c}\text { Q-75 }(\varnothing 3.8- \\
150 \times 150)\end{array}$ & $\begin{array}{c}\text { Q-75 (ø3.8- } \\
150 \times 150)\end{array}$ \\
\hline Profile V1 and V2* & -- & W $310 \times 21$ & W $310 \times 21$ & W $310 \times 21$ & W $310 \times 21$ & W $310 \times 21$ & W $310 \times 21$ & W $310 \times 21$ \\
\hline $\begin{array}{l}\text { Degree of composite interaction } \\
\text { V1 and V2 }\end{array}$ & -- & 0.53 & 0.54 & 0.52 & 0.61 & 0.54 & 0.49 & 0.5 \\
\hline Total number of connectors V1 & un & 48 & 48 & 48 & 54 & 48 & 48 & 48 \\
\hline Number of connectors V2 & un & 32 & 32 & 32 & 36 & 32 & 32 & 32 \\
\hline $\begin{array}{l}\text { Transverse reinforcement V1 and } \\
\text { V2 }\end{array}$ & -- & $\begin{array}{c}16 ø 8 \mathrm{c} / 40 \\
\mathrm{C}=106\end{array}$ & $\begin{array}{c}16 ø 8 \mathrm{c} / 40 \\
\mathrm{C}=91\end{array}$ & $\begin{array}{c}16 ø 8 \mathrm{c} / 40 \\
\mathrm{C}=80\end{array}$ & $\begin{array}{c}16 ø 8 \mathrm{c} / 40 \\
\mathrm{C}=73\end{array}$ & $\begin{array}{c}16 ø 8 \mathrm{c} / 40 \\
\mathrm{C}=66\end{array}$ & $\begin{array}{c}16 ø 8 \mathrm{c} / 40 \\
\mathrm{C}=61\end{array}$ & $\begin{array}{c}16 ø 8 \mathrm{c} / 40 \\
\mathrm{C}=56\end{array}$ \\
\hline Profile V $3 *$ & -- & VS $450 \times 59$ & VS $450 \times 51$ & VS $450 \times 51$ & VS $450 \times 51$ & VS $450 \times 51$ & VS $450 \times 51$ & VS $450 \times 51$ \\
\hline number of connectors & un & 20 & 28 & 30 & 34 & 22 & 38 & 34 \\
\hline Transverse reinforcement V3 & -- & $\begin{array}{c}16 ø 8 \mathrm{c} / 40 \\
\mathrm{C}=109\end{array}$ & $\begin{array}{c}30 ø 8 \mathrm{c} / 23 \\
\mathrm{C}=91\end{array}$ & $\begin{array}{c}38 ø 10 \mathrm{c} / 18 \\
\mathrm{C}=80\end{array}$ & $46 ø 8 \mathrm{c} / 8 \mathrm{C}=73$ & $\begin{array}{c}16 ø 8 \mathrm{c} / 40 \\
\mathrm{C}=70\end{array}$ & $46 ø 8 \mathrm{c} / 8 \mathrm{C}=61$ & $46 ø 8 \mathrm{c} / 8 \mathrm{C}=56$ \\
\hline TOTAL $\mathrm{CO}_{2}$ emission & $\mathrm{kg}$ & 3403.84 & 3671.32 & 3718.71 & 3800.69 & 3529.68 & 3600.44 & 4102.14 \\
\hline TOTAL cost & $\mathrm{R} \$$ & 18780.85 & 19321.05 & 19399.16 & 19622.19 & 18459.14 & 18862.50 & 20209.63 \\
\hline
\end{tabular}


Results show that an increase in the compressive strength of concrete initially results in more $\mathrm{CO}_{2}$ emission. However, at $40 \mathrm{MPa}$ there is a reduction of environmental impact, followed by a tendency to increase for larger values of compressive strength. The most environmentally friendly solution corresponds to an $f_{c k}$ of $20 \mathrm{MPa}$. As such, it is plausible to conclude that increases in $f_{c k}$ interferes with improvements in $\mathrm{CO}_{2}$ emission up to a limit value.

Furthermore, the lowest cost is obtained for $f_{c k}$ equal to $40 \mathrm{MPa}$, implying that the financially optimal solution does not necessarily correspond to the environmentally optimal alternative. If limitations related to environmental aggressiveness are imposed, as stated by Kripakaran et al. [11] concerning the decision-making support system and the application of MGA, a more comprehensive analysis of the results reveals that the best solution from a financial and environmental standpoint is obtained for $f_{c k}$ equal to $40 \mathrm{MPa}$. Figures $5 \mathrm{a}$ and $5 \mathrm{~b}$ present percentages of $\mathrm{CO}_{2}$ emission and cost for each analyzed alternative. It is observed that the steel deck presents the highest percentage of $\mathrm{CO}_{2}$ emission for all resistance classes of concrete, followed in most cases by profiles $\mathrm{V} 1$ and $\mathrm{V} 2$, except for $f_{c k}$ values of $35 \mathrm{MPa}, 45 \mathrm{MPa}$ and $50 \mathrm{MPa}$, in which concrete presents the second highest percentage. Alternatively, Figure $5 \mathrm{~b}$ shows the contribution of each material to the total cost of the structural system. Beams V1 and primary beam V2 figured as the most financially burdensome, followed by an alternation between girder V3 and the steel deck.
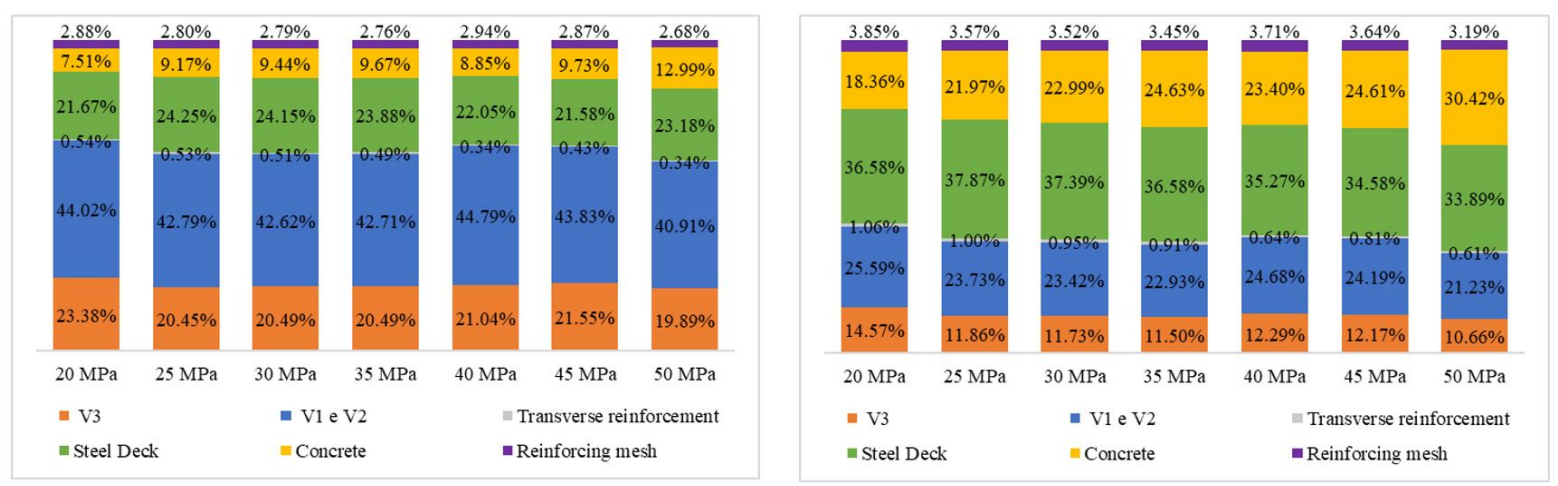

(a) $\mathrm{CO}_{2}$ emission for each element from the optimized(b) Cost for each element from the optimized solution solution for example 1 for example 1

Figure 5. Optimized solution for example 1

The least expensive solution is only $1.71 \%$ cheaper than the solution corresponding to the smallest $\mathrm{CO}_{2}$ emission, which presents a reduction of $3.57 \%$ for this parameter. As such, if a financial limit is imposed, the best possible solution features a compressive strength of concrete equal to $20 \mathrm{MPa}$.

Given the analysis of Figure 5, it is noted that a large portion of $\mathrm{CO}_{2}$ emission is attributed to the steel from secondary beams, girders, and steel deck, reaching up to $85 \%$ of total emissions of the structure for lower $f_{c k}$ values. As the compressive strength of concrete increases, emissions from this material also increase, while emissions from steel are reduced to values around $65 \%$. Furthermore, the largest cost results from steel elements, reaching up to $90 \%$ of the total value for smaller concrete compressive strengths.

The way constraints are imposed by the program indicates the percentage of optimization attributed to each variable, such as the ratios between maximum deflection and allowable deflection $(\Delta \delta)$, applied loads and resistance to shear force $(\Delta V)$ and bending moment $(\Delta M)$. Figures $6 \mathrm{a}$ and $6 \mathrm{~b}$ presents these ratios to SLS and ULS of the beam, primary beam, and girder profiles for example 1 . The imposed constraints show that the smallest ratio corresponds to $\Delta M$, especially for girder V3 if a compressive strength of $40 \mathrm{MPa}$ is adopted for concrete. This indicated that the applied load is close to the resistance stipulated by the ULS. 


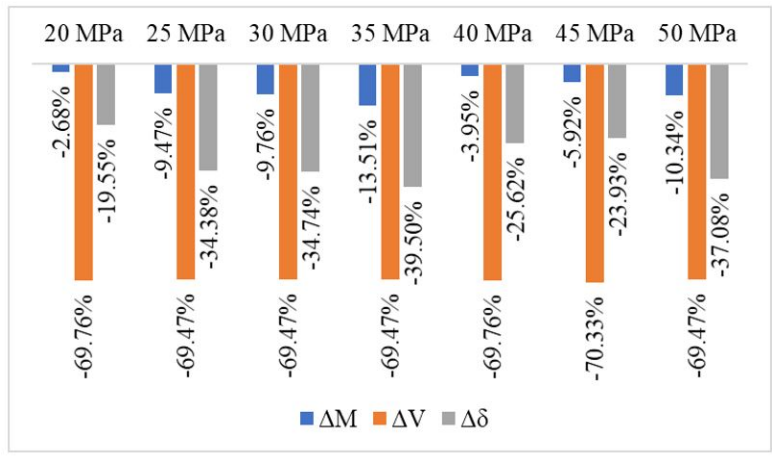

(a) Beam V1 and primary beam V2

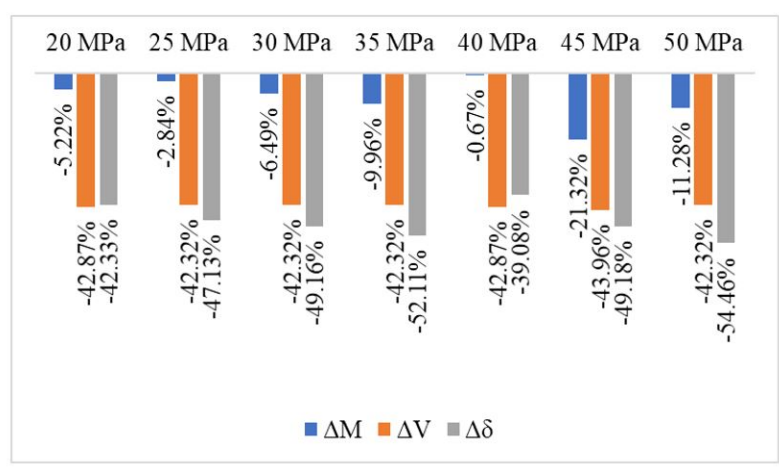

(b) Girder V3

Figure 6. Verification of SLS and ULS

\subsection{Example 2 - Case study of the Nexem building}

This example presents an application of the methodology proposed herein to the Nexem building - Nucleous of Excelence in Metallic Structures (direct translation from Portuguese), shown in Figure 7. This example is also analyzed by Breda et al. [28]. The structure is located at Goiabeiras campus of the Federal University of Espírito Santo (UFES) and features a composite girder and slab system with a constructed area of $264.98 \mathrm{~m}^{2}$.

According to field measurements performed by Breda et al. [28], the system selected for analysis is the classroom located on the first floor, featuring steel deck MF-50 with $0.80 \mathrm{~mm}$ thickness, $15.0 \mathrm{~cm}$ of total height, reinforcing mesh Q-113 $(\varnothing 3.8 \times \varnothing 3.8-100 \times 100)$ and concrete with an $f_{c k}$ of $30 \mathrm{MPa}$. The internal composite beams V1 are simply supported and feature cross-section W $200 \times 31.3$, as shown in Figure 8 .

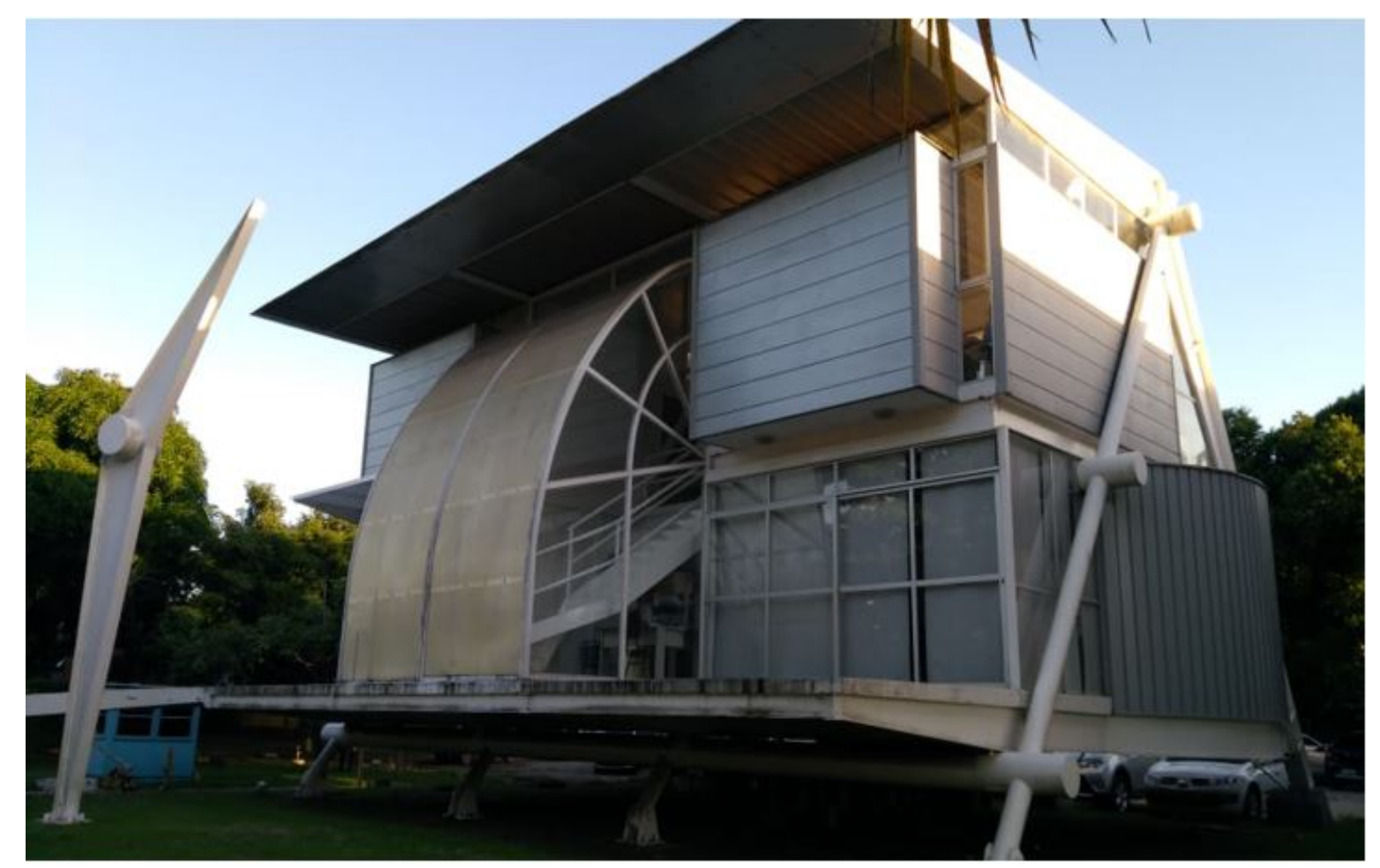

Figure 7. Nexem (Breda et al. [28]) 

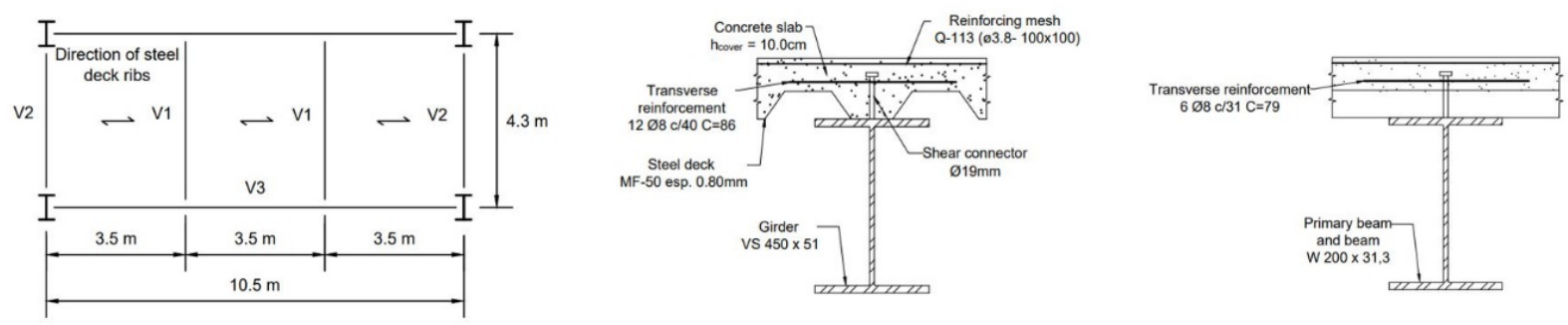

Figure 8. Geometry of the floor system from example 2

The construction was propped, and the characteristic values of dead and live loads, along with the corresponding load factors are given in Table 7.

Table 7. Loads after concrete curing

\begin{tabular}{cccc}
\hline Load type & Load & Characteristic value $\left[\mathbf{k N} / \mathbf{m}^{2}\right]$ & Load factor \\
\hline \multirow{2}{*}{ Dead loads } & Weight of the steel structure & 0.40 & 1.40 \\
\cline { 2 - 4 } & Weight of the flooring & 1.35 & 1.40 \\
\hline Live loads & Serviceability live load & 3.00 & 1.50 \\
\hline
\end{tabular}

Table 8 shows results for the conventional and optimized design of Nexem. Regardless of the optimized design indicating the use of two additional beams V1, a reduction of cross-section geometry is observed for all profiles, resulting in less linear weight and a smaller height. The presence of additional beams also reduced the thickness of the slab.

Table 8. Results for example 2

\begin{tabular}{|c|c|c|c|}
\hline Information & Unit & NEXEM & Optimized solution \\
\hline Number of beams V1 & un & 2 & 4 \\
\hline Steel deck type & -- & MF-50 & MF-50 \\
\hline Steel deck thickness & $\mathrm{mm}$ & 0.80 & 0.80 \\
\hline Maximum span & $\mathrm{m}$ & 3.50 & 2.10 \\
\hline Total height of the slab & $\mathrm{cm}$ & 15.00 & 11.00 \\
\hline Thickness of the concrete layer & $\mathrm{cm}$ & 10.00 & 6.00 \\
\hline Reinforcing steel mesh & -- & Q-113 (ø3.8- 100×100) & Q-75 (ø3.8-150×150) \\
\hline Profile of the beam V1 & -- & W $200 \times 31.3$ & W $200 \times 15$ \\
\hline Degree of composite interaction V1 & -- & 0.40 & 0.43 \\
\hline Total number of connectors V1 & un & 24 & 40 \\
\hline Transverse reinforcementV1 & & $6 ø 8 \mathrm{c} / 31 \mathrm{C}=79^{*}$ & $10 ø 8 \mathrm{c} / 38 \mathrm{C}=72$ \\
\hline Profile of the primary beam V2 & -- & W $200 \times 31.3^{*}$ & W $200 \times 15$ \\
\hline Degree of composite interaction V2 & un & $0.40^{*}$ & 0.43 \\
\hline Total number of connectors V2 & -- & $24 *$ & 20 \\
\hline Transverse reinforcementV2 & & $6 ø 8 \mathrm{c} / 31 \mathrm{C}=79 * *$ & $10 ø 8 \mathrm{c} / 38 \mathrm{C}=72$ \\
\hline Profile of the girder V3 & -- & VS $450 \times 51 * *$ & VS $400 \times 44$ \\
\hline Degree of composite interaction V3 & -- & $0.85^{* *}$ & 0.69 \\
\hline Total number of connectors V3 & un & $38^{* *}$ & 26 \\
\hline Transverse reinforcementV3 & -- & $12 ø 8 \mathrm{c} / 40 \mathrm{C}=86^{* *}$ & $22 ø 8 \mathrm{c} / 40 \mathrm{C}=87$ \\
\hline
\end{tabular}

*Adopted information **Information obtained with the program developed

Results show a reduction in financial and environmental cost for most elements designed with de optimization program. The topology indicated by the program features the same steel deck type adopted for the original design of the building, but remaining components of the slab system are the major contributors for optimizing the design, namely $32 \%$ for concrete and $32.78 \%$ for the reinforcing steel mesh. Even with an increase in the number of beams V1, the program reduces the weight and cost of primary beams V2 and girder V3, by $24.16 \%$ and $15.29 \%$, respectively.

Table 9 shows a comparison between greenhouse gas emission and cost of the optimized program and the existing structural design. 
Table 9. $\mathrm{CO}_{2}$ emission and cost for example 2

\begin{tabular}{lcccccc}
\hline \multirow{2}{*}{ Information } & \multicolumn{2}{c}{ NEXEM } & & \multicolumn{2}{c}{ Optimization program } \\
\cline { 2 - 3 } \cline { 5 - 6 } & $\begin{array}{c}\text { Environmental } \\
\text { impact (kgCO) }\end{array}$ & & Cost (R\$) & & $\begin{array}{c}\text { Environmental } \\
\text { impact (kgCO2) }\end{array}$ & Cost (R\$) \\
\hline Beam V1 & 298.97 & 2797.02 & & 281.33 & 2828.23 \\
\hline Primary beams V2 & 298.97 & 2797.02 & & 140.66 & 1414.12 \\
\hline Girder V3 & 609.41 & 5518.81 & & 522.92 & 4675.17 \\
\hline Transverse reinforcement & 8.52 & 23.69 & & 22.25 & 61.74 \\
\hline Steel deck & 999.3 & 3267.05 & & 999.3 & 3267.05 \\
\hline Concrete & 836.86 & 1793.41 & & 569.06 & 1219.52 \\
\hline Reinforcing steel mesh & 156.36 & 646.91 & & 105.11 & 434.87 \\
\hline TOTAL & 3208.39 & 16843.91 & & 2640.63 & & 13900.70 \\
\hline
\end{tabular}

It must be noted that, except for beams $\mathrm{V} 1$, which presented reduction in $\mathrm{CO}_{2}$ emission (5.9\%), every component that contributed to cost reduction also reduced environmental impact by the following percentages: $29.43 \%$ (V2), $14.19 \%$ (V3), 32\% (concrete) and 32.78\% (reinforcing steel mesh). Overall, the optimization program reduced environmental impact by $17.7 \%$ and cost by $17.47 \%$. Geometries of the floor plan and the cross-section obtained with the optimized procedure are presented in Figure 9.
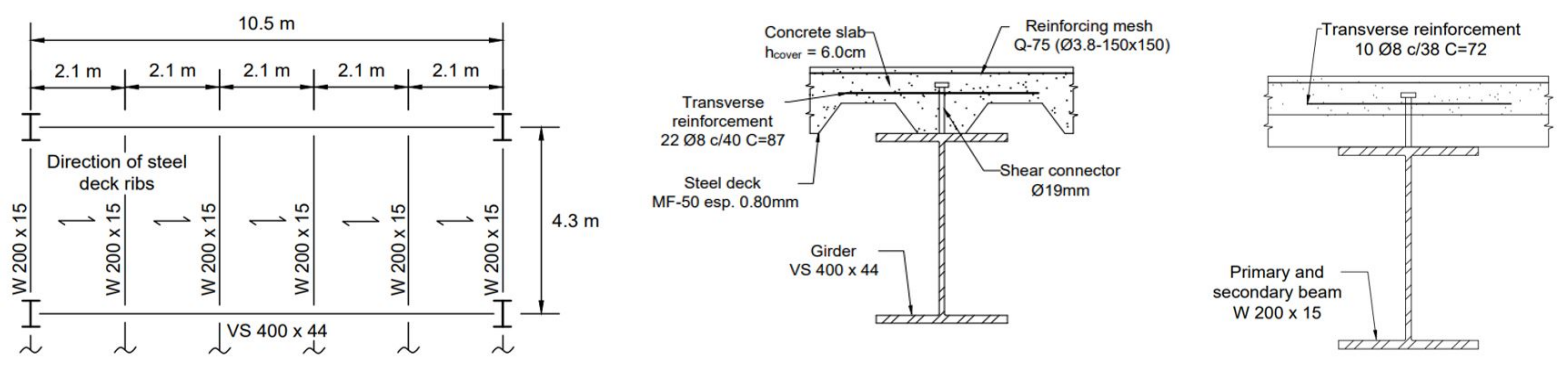

Figure 9. Optimal floor geometry for example 2

Table 10 and Figures 10a and 10b show the influence of concrete strength on the environmental impact of the composite system analyzed here.

Table 10. Results from example 2 for different values of $f_{c k}$

\begin{tabular}{|c|c|c|c|c|c|c|c|c|}
\hline Information & Unit & $20 \mathrm{MPa}$ & $25 \mathrm{MPa}$ & $30 \mathrm{MPa}$ & $35 \mathrm{MPa}$ & $40 \mathrm{MPa}$ & $45 \mathrm{MPa}$ & $50 \mathrm{MPa}$ \\
\hline Number of $\mathrm{V} 1 *$ & un & 4 & 4 & 4 & 4 & 5 & 5 & 4 \\
\hline Steel deck type & -- & MF-50 & MF-75 & MF-50 & MF-50 & MF-50 & MF-50 & MF-50 \\
\hline Steel deck thickness & $\mathrm{mm}$ & 0.80 & 0.80 & 0.80 & 0.80 & 0.80 & 0.80 & 0.80 \\
\hline Maximum span & $\mathrm{m}$ & 210.00 & 210.00 & 210.00 & 240.00 & 200.00 & 200.00 & 230.00 \\
\hline Total height of the slab & $\mathrm{cm}$ & 12.00 & 11.00 & 11.00 & 11.00 & 11.00 & 11.00 & 11.00 \\
\hline $\begin{array}{l}\text { Thickness of the } \\
\text { concrete layer }\end{array}$ & $\mathrm{m}$ & 7.00 & 6.00 & 6.00 & 6.00 & 6.00 & 6.00 & 6.00 \\
\hline Reinforcing steel mesh & -- & $\begin{array}{c}\text { Q-75 } \\
(ø 3.8-150 \times 150)\end{array}$ & $\begin{array}{c}\text { Q-75 } \\
(ø 3.8-150 \times 150)\end{array}$ & $\begin{array}{c}\text { Q-75 } \\
(ø 3.8-150 \times 150)\end{array}$ & $\begin{array}{c}\text { Q-75 } \\
(ø 3.8-150 \times 150)\end{array}$ & $\begin{array}{c}\text { Q-75 } \\
(ø 3.8-150 \times 150)\end{array}$ & $\begin{array}{c}\text { Q-75 } \\
(ø 3.8-150 \times 150)\end{array}$ & $\begin{array}{c}\text { Q-75 } \\
(ø 3.8-150 \times 150)\end{array}$ \\
\hline Profile V1 and V2* & -- & W $150 \times 13$ & W $150 \times 13$ & W $200 \times 15$ & W $200 \times 15$ & W $150 \times 13$ & W $200 \times 15$ & W $150 \times 13$ \\
\hline $\begin{array}{l}\text { Degree of composite } \\
\text { interaction } \mathrm{V} 1 \mathrm{e} \mathrm{V} 2\end{array}$ & -- & 0.45 & 0.67 & 0.43 & 0.58 & 0.78 & 0.52 & 0.4 \\
\hline $\begin{array}{c}\text { Total number of } \\
\text { connectors V1 }\end{array}$ & un & 32 & 48 & 40 & 48 & 70 & 60 & 32 \\
\hline
\end{tabular}


Table 10. Continued...

\begin{tabular}{|c|c|c|c|c|c|c|c|c|}
\hline Information & Unit & $20 \mathrm{MPa}$ & $25 \mathrm{MPa}$ & $30 \mathrm{MPa}$ & $35 \mathrm{MPa}$ & $40 \mathrm{MPa}$ & $45 \mathrm{MPa}$ & $50 \mathrm{MPa}$ \\
\hline $\begin{array}{l}\text { Number of connectors } \\
\text { V2 }\end{array}$ & un & 16 & 24 & 20 & 24 & 28 & 24 & 16 \\
\hline $\begin{array}{c}\text { Transverse } \\
\text { reinforcement V1 e V2 }\end{array}$ & -- & $10 ø 8 \mathrm{c} / 38 \mathrm{C}=103$ & $10 \varnothing 8 \mathrm{c} / 38 \mathrm{C}=90$ & $10 ø 8 \mathrm{c} / 38 \mathrm{C}=79$ & $10 ø 8 \mathrm{c} / 38 \mathrm{C}=72$ & $10 \varnothing 8 \mathrm{c} / 38 \mathrm{C}=66$ & $10 ø 8 \mathrm{c} / 38 \mathrm{C}=60$ & $10 \varnothing 8 \mathrm{c} / 38 \mathrm{C}=55$ \\
\hline Girder V3* & -- & VS $400 \times 44$ & VS $400 \times 44$ & VS $400 \times 44$ & VS $400 \times 44$ & VS $400 \times 38$ & VS $400 \times 37$ & VS $400 \times 44$ \\
\hline $\begin{array}{l}\text { Degree of composite } \\
\text { interaction }\end{array}$ & -- & 0.67 & 0.74 & 0.69 & 0.68 & 0.8 & 0.88 & 0.64 \\
\hline Number of connectors & un & 32 & 30 & 26 & 26 & 26 & 28 & 24 \\
\hline $\begin{array}{c}\text { Transverse } \\
\text { reinforcementV3 }\end{array}$ & -- & $22 ø 8 \mathrm{c} / 40 \mathrm{C}=114$ & $22 ø 8 \mathrm{c} / 40 \mathrm{C}=100$ & $22 ø 8 \mathrm{c} / 40 \mathrm{C}=87$ & $22 ø 8 \mathrm{c} / 40 \mathrm{C}=78$ & $22 ø 8 \mathrm{c} / 40 \mathrm{C}=71$ & $22 ø 8 \mathrm{c} / 40 \mathrm{C}=66$ & $22 ø 8 \mathrm{c} / 40 \mathrm{C}=61$ \\
\hline TOTAL $\mathrm{CO}_{2}$ emission & $\mathrm{kg}$ & 2576.40 & 2549.68 & 2640.63 & 2693.10 & 2659.88 & 2767.10 & 2830.83 \\
\hline TOTAL cost & $\mathrm{R} \$$ & 13357.91 & 13513.32 & 13900.70 & 14075.37 & 13791.62 & 14328.19 & 13711.98 \\
\hline
\end{tabular}

*V1: Beams; V2: Primary beam; V3: Girder

The table indicates the smallest environmental impact for an $f_{c k}$ of $25 \mathrm{MPa}$ and the cheapest solution for a compressive strength of $20 \mathrm{MPa}$. Therefore, increases in the compressive strength of concrete do not improve the optimized solution and the most financially optimum alternative does not correspond to the lowest environmental impact. The optimization program arrived at the same solution of steel deck as the original design of NEXEM, given that the steel sheet from the table used already presented the minimum dimensions.

An assessment of optimized solution concerning environmental impact and cost indicates that the difference of $\mathrm{CO}_{2}$ emission for finding the best cost is $1.04 \%$, smaller than what is observed for the cost of $1.15 \%$.

Based on Figure 10a, the largest portion of $\mathrm{CO}_{2}$ emission stems from the steel deck, with an average of 37.57\%, while the most expensive item is the girder V3, corresponding, on average, to $33.64 \%$ of the total cost (see Figure 10b).

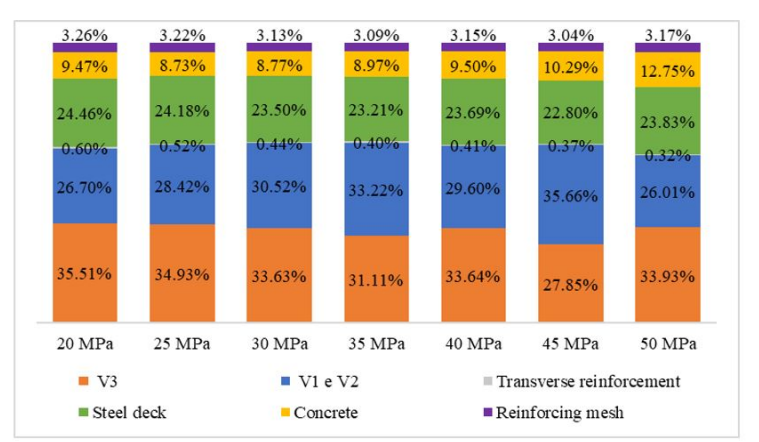

(a) $\mathrm{CO}_{2}$ emission for each element from the optimized solution for example 2

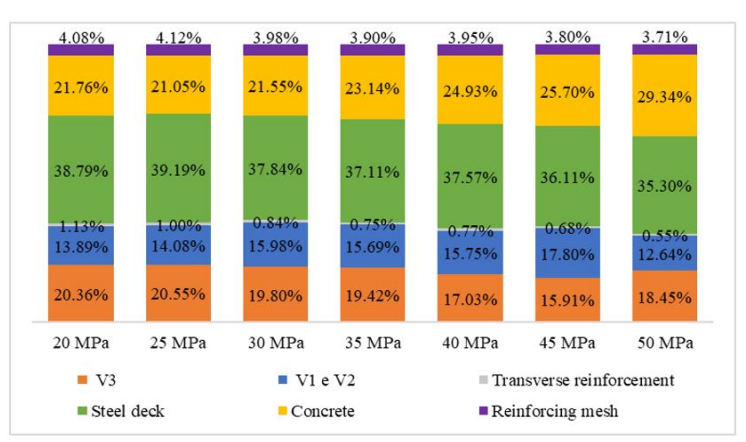

(b) Cost for each element from the optimized solution for example 2

Figure 10. Optimized solution for example 2

Further, steel generates the largest material consumption of the global floor system, which represents the equivalent of $76.06 \%$ of $\mathrm{CO}_{2}$ emission and $90.22 \%$ of the total cost.

Figures $11 \mathrm{a}$ and $11 \mathrm{~b}$ present the SLS and the ULS for the beam V1, primary beam V2 and girder V3. It is noted that percentages for SLS and ULS are large for the design of beam V1 and primary beam V2. Girder V3, however, presents smaller values for each limit state, especially for $\Delta \delta$, that is, the design value is close to the allowable limit prescribed by the SLS. 


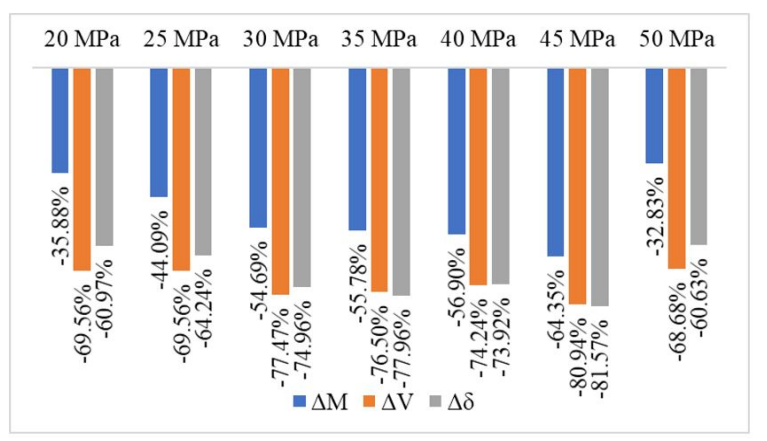

(a) Beam V1 and primary beam V2

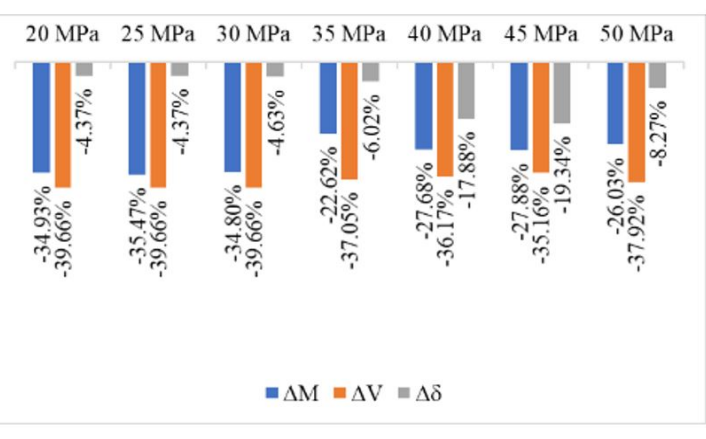

(b) Girder V3

Figure 11. Verification of SLS and ULS

\section{CONCLUSIONS}

This present study proposed a formulation for optimizing the design of a floor system featuring steel-concrete composite girders and slabs, with the objective of determining a structural system of minimal financial and environmental costs.

The formulation was validated by two numerical examples, the first of which originally presented by Fakury et al. [27] and the second corresponding to an existing structure featuring the same composite floor system in its structure, Nexem.

The first example showed that, despite the optimized design increasing the number of beams, amplifying financial and environmental costs attributed to these elements, the solution presents lighter girders and reduced the geometry of the composite slab. Overall, the solution reduced $\mathrm{CO}_{2}$ emission by $12.32 \%$ and cost by $9.11 \%$. If limits according to the class of environmental aggressiveness are imposed on the values of concrete strength, alternatives in accordance to studies conducted by Kripakaran et al. [11] on a decision making support system and application of MGA, indicate an optimal solution corresponding to an $f_{c k}$ of $40 \mathrm{MPa}$.

In similar fashion to the first case study, results from the second example present an increase in the number of beams and lighter profiles. Consequently, the typology of the composite slab was subjected to reductions in all components except the steel deck. Overall, the optimized design reduced environmental impact by $17.7 \%$ and cost by $17.47 \%$.

Both examples indicated a reduction in environmental impact in comparison with the original solution, since most elements adopted for the optimized design presented reductions in geometry, and consequently, in weight. It is also noted that optimizing $\mathrm{CO}_{2}$ emission reduced the cost of the structure, indicating that structural weight is related to cost and environmental parameters.

The detailing of the cost and $\mathrm{CO}_{2}$ emission of the materials included in the optimization shows a larger environmental impact attributed to steel elements, with more than $75 \%$ in both examples. Likewise, the largest costs also result from steel elements, reaching a value of $90 \%$ in relation to the cost of the concrete used. As such, the materials that generate the largest $\mathrm{CO}_{2}$ emission also represent the largest portion of global costs.

In closure, both examples showed that the steel deck presents the largest percentage of environmental impact for the entire system, while primary beam and beam profiles with the same cross-section presented the largest cost. Furthermore, it was seen that increasing $f_{c k}$ does not improve environmental factors, however, if standardized restrictions are imposed on this parameter, the solution corresponding to the lowest environmental impact is not necessarily the same.

\section{ACKNOWLEDGEMENTS}

The authors would like to thank Capes and Fapes for the support given to the postgraduate program in civil engineering at UFES and CNPq for the research grant provided.

\section{REFERENCES}

[1] H. T. Öztürk, T. Dede, and E. Türker, "Optimum design of reinforced concrete counterfort retaining walls using TLBO, Jaya algorithm," Structures, vol. 25, pp. 285-296, 2020, http://dx.doi.org/10.1016/j.istruc.2020.03.020.

[2] E. N. Kalemci, S. B. İkizler, T. Dede, and Z. Angın, "Design of reinforced concrete cantilever retaining wall using Grey wolf optimization algorithm," Structures, vol. 23, pp. 245-253, 2020, http://dx.doi.org/10.1016/j.istruc.2019.09.013. 
[3] H. R. Maier, S. Razavi, Z. Kapelan, L. S. Matott, J. Kasprzyk, and B. A. Tolson, "Introductory overview: Optimization using evolutionary algorithms and other metaheuristics," Environ. Model. Softw., vol. 114, pp. 195-213, 2019, http://dx.doi.org/10.1016/j.envsoft.2018.11.018.

[4] M. Shahnewaz, A. Rteil, and M. S. Alam, "Shear strength of reinforced concrete deep beams: a review with improved model by genetic algorithm and reliability analysis," Structures, vol. 23, pp. 494-508, 2020, http://dx.doi.org/10.1016/j.istruc.2019.09.006.

[5] E. Zhu et al., "Optimizing reinforced concrete beams under different load cases and material mechanical properties using genetic algorithms," Steel Compos. Struct., vol. 34, pp. 467-485, 2020. https://doi.org/http://dx.doi.org/10.12989/scs.2020.34.4.467.

[6] A. F. Tormen, Z. M. C. Pravia, F. B. Ramires, and M. Kripka, "Optimization of steel-concrete composite beams considering cost and environmental impact," Steel Compos. Struct., vol. 34, pp. 409-421, 2020. https://doi.org/http://dx.doi.org/10.12989/scs.2020.34.3.409.

[7] M.-B. Prendes-Gero, A. Bello-García, J.-J. del Coz-Díaz, F.-J. Suárez-Domínguez, and P.-J. García Nieto, "Optimization of steel structures with one genetic algorithm according to three international building codes," Rev. Constr., vol. 17, pp. 47-59, 2018, http://dx.doi.org/10.7764/RDLC.17.1.47.

[8] J. Malveiro, D. Ribeiro, C. Sousa, and R. Calçada, "Model updating of a dynamic model of a composite steel-concrete railway viaduct based on experimental tests," Eng. Struct., vol. 164, pp. 40-52, 2018, http://dx.doi.org/10.1016/j.engstruct.2018.02.057.

[9] M. H. Ha, Q. A. Vu, and V. H. Truong, "Optimum design of stay cables of steel cable-stayed bridges using nonlinear inelastic analysis and genetic algorithm," Structures, vol. 16, pp. 288-302, 2018, http://dx.doi.org/10.1016/j.istruc.2018.10.007.

[10] M. Z. Abd Elrehim, M. A. Eid, and M. G. Sayed, "Structural optimization of concrete arch bridges using Genetic Algorithms," Ain Shams Eng J, vol. 10, no. 3, pp. 507-516, 2019, http://dx.doi.org/10.1016/j.asej.2019.01.005.

[11] P. Kripakaran, B. Hall, and A. Gupta, "A genetic algorithm for design of moment-resisting steel frames," Struct. Multidiscipl. Optim., vol. 44, no. 4, pp. 559-574, 2011, http://dx.doi.org/10.1007/s00158-011-0654-7.

[12] J. F. Santoro and M. Kripka, "Minimizing environmental impact from optimized sizing of reinforced concrete elements," Comput. Concr., vol. 25, pp. 111-118, 2020.

[13] T. Žula, S. Kravanja, and U. Klansek, "MINLP optimization of a composite I beam floor system," Steel Compos. Struct., vol. 22, no. 5, pp. 1163-1192, 2016, http://dx.doi.org/10.12989/scs.2016.22.5.1163.

[14] J. C. Matos, I. B. Valente, P. J. S. Cruz, and V. N. Moreira, "Probabilistic-based assessment of composite steel-concrete structures through an innovative framework," Steel Compos. Struct., vol. 20, no. 6, pp. 1345-1368, 2016, http://dx.doi.org/10.12989/scs.2016.20.6.1345.

[15] T. Dede, "Jaya algorithm to solve single objective size optimization problem for steel grillage structures," Steel Compos. Struct., vol. 26, pp. 163-170, 2018. https://doi.org/http://dx.doi.org/10.12989/scs.2018.26.2.163.

[16] M. Shariati et al., "Application of Extreme Learning Machine (ELM) and Genetic Programming (GP) to design steel-concrete composite floor systems at elevated temperatures," Steel Compos. Struct., vol. 33, pp. 319-332, 2019. https://doi.org/https://doi.org/10.12989/scs.2019.33.3.319.

[17] A. Kaveh and A. S. M. Abadi, "Cost optimization of a composite floor system using an improved harmony search algorithm," $J$. Construct. Steel Res., vol. 66, no. 5, pp. 664-669, 2010, http://dx.doi.org/10.1016/j.jcsr.2010.01.009.

[18] S. Kravanja, T. Žula, and U. Klanšek, "Multi-parametric MINLP optimization study of a composite I beam floor system," Eng. Struct., vol. 130, pp. 316-335, 2017, http://dx.doi.org/10.1016/j.engstruct.2016.09.012.

[19] R. L. Pedro, J. Demarche, L. F. F. Miguel, and R. H. Lopez, "An efficient approach for the optimization of simply supported steelconcrete composite I-girder bridges," Adv. Eng. Softw., vol. 112, pp. 31-45, 2017, http://dx.doi.org/10.1016/j.advengsoft.2017.06.009.

[20] A. R. Silva and T. A. Rodrigues, "Optimized dimensioning of steel-concrete composite beams," Rev. IBRACON Estrut. Mater., vol. 12, no. 6, pp. 1428-1453, 2019, http://dx.doi.org/10.1590/s1983-41952019000600012.

[21] A. R. Silva, F. A. Neves, and J. B. M. Sousa, "Optimization of partially connected composite beams using nonlinear programming," Structures, vol. 25, pp. 743-759, 2020, http://dx.doi.org/10.1016/j.istruc.2020.03.007.

[22] H. Gervásio, "The sustainability of steel and metallic structures” in Construmetal - Lat. Am. Met. Constr. Congr., São Paulo, 2008.

[23] I. Paya-Zaforteza, V. Yepes, A. Hospitaler, and F. González-Vidosa, "CO2-optimization of reinforced concrete frames by simulated annealing," Eng. Struct., vol. 31, no. 7, pp. 1501-1508, 2009, http://dx.doi.org/10.1016/j.engstruct.2009.02.034.

[24] International Energy Agency, Global Status Report for Buildings and Construction. 2019.

[25] Mathworks, Inc., Mathworks R2015a. 2015.

[26] Associação Brasileira de Norma Técnicas, Projeto de Estruturas de Aço e de Estruturas Mistas de Aço e Concreto de Edifícios Procedimento, ABNT NBR 8800:2008, 2008.

[27] R. Fakury, A. Silva, and R. Caldas, Dimensionamento de Elementos Estruturais de Aço e Mistos de Aço e Concreto. São Paulo: Pearson Education do Brasil, 2016. 
[28] B. D. Breda, T. C. Pietralonga, and É. C. Alves, "Optimization of the structural system with composite beam and composite slab using Genetic Algorithm," Rev. IBRACON Estrut. Mater., vol. 13, no. 6, pp. e13602, 2020, http://dx.doi.org/10.1590/s198341952020000600002.

[29] GERDAU. "Perfil estrutural.” https://www2.gerdau.com.br/produtos/perfil-estrutural (accessed May. 17, 2020).

[30] METFORM. "Steel Deck: a solução definitiva em lajes.” http://www.metform.com.br/ wordpress/wpcontent/ uploads/2015/05/steel_deck_metform.pdf (accessed May 17, 2020).

[31] Worldsteel Association, LCI Data for Steel Products, 2019.

[32] Sistema Nacional de Pesquisa de Custos e Índices da Construção Civil. http://www.caixa.gov.br/poder-publico/apoio-poderpublico/sinapi/Paginas/default.aspx (accessed Mar. 20, 2020).

[33] F. C. R. Cordeiro, "Análise de produtividade da mão-de-obra e composição de custos do serviço de execução da laje steel deck," Undergraduate thesis, UFSC, Florianópolis, 2016.

[34] M. S. Estruturas Metálicas. "Painel steel deck." https://rms-estruturas-metalicas.webnode.com.pt/products/painel-steel-deck-apartirde-r\%24-46\%2C35-m\%C2\%B2/ (accessed Mar. 19, 2020).

Author contributions: PATA: conceptualization, data curation, formal analysis, methodology, writing; MC: conceptualization, data curation, formal analysis, methodology, writing; BDB: data curation, formal analysis, methodology, writing; AFGC: conceptualization, data curation, formal analysis, methodology, supervision, writing ECA: conceptualization, data curation, formal analysis, methodology, supervision, writing.

Editors: Mark Alexander, Guilherme Aris Parsekian 


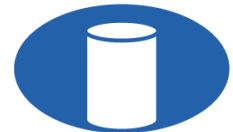

IBRACON Structures and Materials Journal

Revista IBRACON de Estruturas e Materiais

IBRACON

ISSN 1983-4195 ismj.org

ERRATUM

\section{Erratum}

Paulo Augusto T. Arpini ${ }^{\mathrm{a}}$

Mayane C. Loureiro ${ }^{\mathrm{a}}(\mathrm{C}$

Breno D. Breda ${ }^{a}$ (i)

Adenílcia F. Calenzani ${ }^{\mathrm{a}}$ (1)

Élcio C. Alves ${ }^{\mathrm{a}}$ (D)

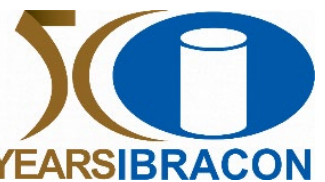

${ }^{a}$ Universidade Federal do Espírito Santo - UFES, Departamento de Engenharia Civil, Vitória, ES, Brasil

In the article "Optimum design of a composite floor system considering environmental and economic impacts", DOI number https://doi.org/10.1590/S1983-41952022000300002, published in IBRACON Structures and Materials Journal ISSN 1983-4195, v.15, n.3, e 15302, 2022, on page 1-17:

\section{RESULTS AND DISCUSSIONS}

Where it reads:

Table 1. $\mathrm{CO}_{2}$ emission of materials

\begin{tabular}{|c|c|c|c|c|c|c|c|}
\hline \multirow[t]{2}{*}{ Material } & \multirow[t]{2}{*}{ Unit } & $\begin{array}{c}\mathrm{CO}_{2} \\
\text { emissions }\end{array}$ & \multirow[t]{2}{*}{ Reference } & \multirow[t]{2}{*}{ Material } & \multirow[t]{2}{*}{ Unit } & $\begin{array}{c}\mathrm{CO}_{2} \\
\text { emissions }\end{array}$ & \multirow[t]{2}{*}{ Reference } \\
\hline & & $\left(\mathrm{kgCO}_{2}\right)$ & & & & $\left(\mathrm{kgCO}_{2}\right)$ & \\
\hline Concrete $20 \mathrm{MPa}$ & $\mathrm{m}^{3}$ & 130.68 & & Steel deck & $\mathrm{kg}$ & 26.38 & \multirow{5}{*}{$\begin{array}{c}\text { Worldsteel } \\
\text { Association } \\
{[31]}\end{array}$} \\
\hline Concrete $25 \mathrm{MPa}$ & $\mathrm{m}^{3}$ & 139.88 & & Steel profile & & & \\
\hline Concrete $30 \mathrm{MPa}$ & $\mathrm{m}^{3}$ & 148.28 & & $\begin{array}{l}\text { Studbolt shear } \\
\text { connector }\end{array}$ & $\mathrm{kg}$ & 11.16 & \\
\hline Concrete $35 \mathrm{MPa}$ & $\mathrm{m}^{3}$ & 162.36 & $\begin{array}{l}\text { Santoro and Kripka } \\
{[12]}\end{array}$ & $\begin{array}{l}\text { Reinforcing steel } \\
\text { mesh }\end{array}$ & \multirow{2}{*}{$\mathrm{kg}$} & \multirow{2}{*}{19.24} & \\
\hline Concrete $40 \mathrm{MPa}$ & $\mathrm{m}^{3}$ & 172.77 & & $\begin{array}{l}\text { Steel CA50, } 8 \mathrm{~mm} \text {, } \\
\text { reinforcement bar }\end{array}$ & & & \\
\hline Concrete $45 \mathrm{MPa}$ & $\mathrm{m}^{3}$ & 185.32 & & & & & \\
\hline Concrete $50 \mathrm{MPa}$ & $\mathrm{m}^{3}$ & 216.40 & & & & & \\
\hline
\end{tabular}


It should be read:

Table 1. $\mathrm{CO}_{2}$ emission of materials

\begin{tabular}{|c|c|c|c|c|c|c|c|}
\hline \multirow[t]{2}{*}{ Material } & \multirow[t]{2}{*}{ Unit } & $\underset{\text { emissions }}{\mathrm{CO}_{2}}$ & \multirow[t]{2}{*}{ Reference } & \multirow[t]{2}{*}{ Material } & \multirow[t]{2}{*}{ Unit } & $\begin{array}{c}\mathrm{CO}_{2} \\
\text { emissions }\end{array}$ & \multirow[t]{2}{*}{ Reference } \\
\hline & & $\left(\mathrm{kgCO}_{2}\right)$ & & & & $\left(\mathrm{kgCO}_{2}\right)$ & \\
\hline Concrete $20 \mathrm{MPa}$ & $\mathrm{m}^{3}$ & 130.68 & & Steel deck & $\mathrm{kg}$ & 2.638 & \multirow{5}{*}{$\begin{array}{c}\text { Worldsteel } \\
\text { Association } \\
\text { [31] }\end{array}$} \\
\hline Concrete $25 \mathrm{MPa}$ & $\mathrm{m}^{3}$ & 139.88 & & Steel profile & & & \\
\hline Concrete $30 \mathrm{MPa}$ & $\mathrm{m}^{3}$ & 148.28 & & $\begin{array}{l}\text { Studbolt shear } \\
\text { connector }\end{array}$ & $\mathrm{kg}$ & 1.116 & \\
\hline Concrete $35 \mathrm{MPa}$ & $\mathrm{m}^{3}$ & 162.36 & $\begin{array}{l}\text { Santoro and Kripka } \\
{[12]}\end{array}$ & $\begin{array}{l}\text { Reinforcing steel } \\
\text { mesh }\end{array}$ & \multirow{2}{*}{$\mathrm{kg}$} & \multirow{2}{*}{1.924} & \\
\hline Concrete $40 \mathrm{MPa}$ & $\mathrm{m}^{3}$ & 172.77 & & $\begin{array}{l}\text { Steel CA } 50, \varnothing 8 \mathrm{~mm} \text {, } \\
\text { reinforcement bar }\end{array}$ & & & \\
\hline Concrete $45 \mathrm{MPa}$ & $\mathrm{m}^{3}$ & 185.32 & & & & & \\
\hline Concrete $50 \mathrm{MPa}$ & $\mathrm{m}^{3}$ & 216.40 & & & & & \\
\hline
\end{tabular}

